Article

\title{
Detecting Coastline Change with All Available Landsat Data over 1986-2015: A Case Study for the State of Texas, USA
}

\author{
Nan Xu \\ Ministry of Education Key Laboratory for Earth System Modelling, Department of Earth System Science, \\ Tsinghua University, Beijing 100084, China; xun14@mails.tsinghua.edu.cn
}

Received: 6 December 2017; Accepted: 6 March 2018; Published: 14 March 2018

\begin{abstract}
Coastline change often results from social and natural factors, such as human activities in the coastal zone, long-term and short-term sea level change, hurricane occurrences, subsequent recovery, and so on. Tracking coastline change is essential to deepen our understanding of coastal responses to these factors. Such information is also required for land use planning and sustainable development of coastal zones. In this context, we aimed to collect all available Landsat data (TM: Thematic Mapper, ETM+: Enhanced Thematic Mapper Plus and OLI: Operational Land Imager) over 1986-2015 for tracking the coastline dynamic and estimating its change rate in the State of Texas, USA. First, the land vs. water maps at an annual scale were derived from the satellite images. The border between land and water represents the coastline in this study. Second, the annual land area was obtained to characterize the coastline dynamic and a linear regression model was used for estimating the change rate. We also analyzed the potential driving factors of the observed coastline change. The results reveal that the coastline in the State of Texas changed at a rate of $-0.154 \pm 0.063 \mathrm{~km}^{2} /$ year from 1986 to 2015, which indicates that the coastline has mainly experienced an erosion over the past three decades. Specifically, $52.58 \%$ of the entire coastline retreated to the land while a $47.42 \%$ portion advanced to the ocean. Long-term sea level rise can result in the erosion of coastline. Hurricane occurrences can explain the relatively strong coastline erosion. Besides, significant difference between the coastline change rate with a higher curvature and a lower curvature was observed. This study establishes a general method for detecting coastline change at large spatial and long-term temporal scales, by using remote sensing that can give fundamental information on coastline change. This is important for making scientific and reasonable policies of sustainable development of coastal zones.
\end{abstract}

Keywords: coastline change; beach; sea level; hurricane; remote sensing; State of Texas

\section{Introduction}

Coastline retreat is a potential consequence of climate-change driven sea-level rise, as a result of permanent passive submersion and coastal erosion [1-3]. The landfall of a hurricane often intensely changes the coastline position in a short period [4]. Additionally, increasing anthropic activities in coastal areas, such as beach nourishment, port construction and tourism development, tends to change the coastal environment and reshape the coastline [5-8].

Tracking the coastline change can be used not only to investigate the potential association between spatial-temporal patterns of sea-level rise and those of coastline changes, but also make it possible to provide fundamental information for government officials and coastal managers to make scientific and rational policies for land use planning and sustainable development of coastal zones $[9,10]$. Therefore, it is necessary to track the coastline dynamic at large spatial scales and over long time periods, especially for sandy coastlines as the world's coastlines are dominated by sandy shores [11]. 
The change of coastline position has been selected as a proxy for monitoring the environmental change in coastal zone [12], and its long-term trend is important for a better understanding of the coastal response to sea level rise and further for better modeling and prediction of coastline change [13].

Numerous indicators have been proposed for different purposes across different criteria and data sources for representing the location of the coastline [14]. For example, the instantaneous land vs. water boundary (i.e., waterline) is a basic indicator of coastline location [15], which is obvious and easily identified for most coastlines with relatively simple morphologies, such as those coastlines with beaches and rocky outcrops. A transect-based indicator was proposed for these coastlines [16]. However, the waterline is more fragmented and difficult to identify for some coastlines with complex morphologies such as those around river deltas and salt marshes [17]. Correspondingly, the transect-based indicator fails to characterize the coastline position and its change over time. Under these circumstances, a sub-pixel level area-based indicator that covers the land-water boundary has been proposed to represent coastlines with subtle changes (i.e., the change within one pixel) while a pixel level area-based indicator has been developed to represent coastlines with significant changes (i.e., the change greater than one pixel) $[18,19]$. However, for the sub-pixel level area-based indicator, it is difficult to deal with those situations where the coastline change exceeds the size of one pixel. The estimated change rate serves no practical purpose when the coastline crosses one pixel. For the pixel level area-based indicator, it is difficult to generate the value of coastline change rate along the coast.

Besides, because of the interaction between land and water, the dynamic coastline experiences continuous change derived from a range of coastal processes at various timescales, such as long-term trend, seasonal variation, tidal-induced water level fluctuation, hurricane-driven regime shift and disturbance of human activity [20-22]. The significant variables (e.g., tidal-induced water level fluctuation and hurricane-driven regime shift) would have further impact on the long-term estimation of coastline change.

Some studies have been already carried out for reducing such impact. Yu et al. [23] has attempted to use satellite images obtained at similar tidal heights and under clear sky conditions to reduce the effect of tide-induced water level fluctuations on the estimation of coastline change. However, the necessary data are often biased and inaccessible, and consequently insufficient for monitoring the coastline change at a larger spatial scale. Only nine images over the period from 1987 to 2008 in this study were available in west-central Florida that met the requirement of tidal range, despite the greatest amount of Landsat images in the USA [23]. In addition, Chen et al. [24] has done the tidal correction using high spatial resolution satellite images and real-time data of tidal level to reduce the impact of tidal level variability on estimation of coastline change. Such models may not be adaptable to the study areas where the coastal topography is lacking.

To date, many studies used only several temporal images to derive the rate of coastline change [19,25-27]. Increasing the observations of coastline appears particularly relevant for reducing the impact of variability of instantaneous coastline position on the estimation of coastline change.

Remotely sensed data have been widely used for coastline delineation and change quantification [25-27] as it is a cost-effective option compared with other data sources including aerial photographs [19], light detection and ranging (LIDAR) data [28], video images [29] and global positioning systems (GPS) data [30]. Among various images, Landsat imagery appears more suitable for frequently identifying the land vs. water boundary at large scale [31-33]. Further, the annual mean coastline (i.e., land vs. water boundary), obtained by averaging many coastline positions for one year, is able to characterize the temporal change of coastline at an annual scale [34].

The State of Texas is a typical area dominated by sandy beaches and its coastline suffered from sea level variation and the landfall of hurricanes $[35,36]$. In this context, this study took the State of Texas as the study area and collected all available Landsat imageries over the period of 1986-2015 for a long-term trend estimation of coastline change and assessing its association with the sea level variation, hurricanes and alongshore sediment transport. The approach consisted of: (i) producing the 
time series of land vs. water maps; (ii) characterizing the spatial-temporal change of the border of land and water; (iii) examining the association between coastline change, sea level variation, hurricanes and alongshore sediment transport.

\section{Study Area and Materials}

\subsection{Study Area}

The study was implemented the State of Texas, which is located in the south central part of the USA, extending between $93^{\circ} 31^{\prime} \mathrm{W}-106^{\circ} 39^{\prime} \mathrm{W}$ and $25^{\circ} 50^{\prime} \mathrm{N}-36^{\circ} 30^{\prime} \mathrm{N}$ (Figure 1). The coastline presents various forms, such as pelagic coastline fronting the open ocean and more sheltered coastline in the bays. In this study, only the pelagic coastline fronting the open ocean was considered, which is mainly occupied by beach.

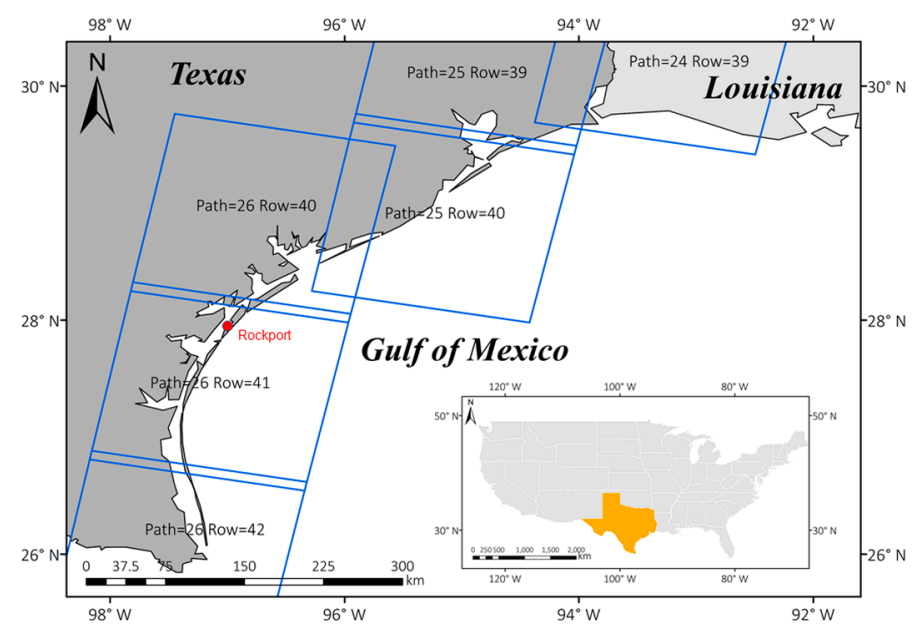

Figure 1. Location of the State of Texas and the distribution of Landsat scenes. Blue polygons represent the positions of Landsat imagery and red dot represents the location of Rockport station mentioned in Section 2.5 .

The rates of sea level rise have varied from between 0 to $9 \mathrm{~mm}$ /year over the last few decades, and the rates are higher than those of most other states in the USA [37]. Over the past decades, Texas has experienced some hurricanes [38]. For example, Hurricane Ike caused extensive damage with a significant storm surge and widespread coastal flooding [39], which made landfall near Galveston, Texas in September 2008. Also, this hurricane resulted in great casualties and property losses [40,41].

\subsection{Remotely Sensed Data}

All available Landsat Surface Reflectance Climate Data Record (Landsat CDR) (TM: Thematic Mapper, ETM+: Enhanced Thematic Mapper Plus and OLI: Operational Land Imager, $30 \mathrm{~m}$ ) over the period 1986-2015 were used in this study. The six Landsat scenes covering the coastal zone of State of Texas were presented in Figure 1. All images had been pre-processed to L1T level (i.e., Standard Terrain Correction). The geo-registration is consistent and within prescribed tolerances (i.e., $<12 \mathrm{~m}$ root mean square error) (https://lta.cr.usgs.gov/LETMP). Note that atmospheric correction is not conducted for L1T level products. According to some previous studies [42,43], the atmospheric correction is not needed for land cover classification. Such high-quality Landsat data is suitable for time series analysis. A total of 4357 scenes of Landsat images were included for this study. All of the detailed information was summarized in Table 1. Figure 2a presents the temporal distribution of Landsat images. 

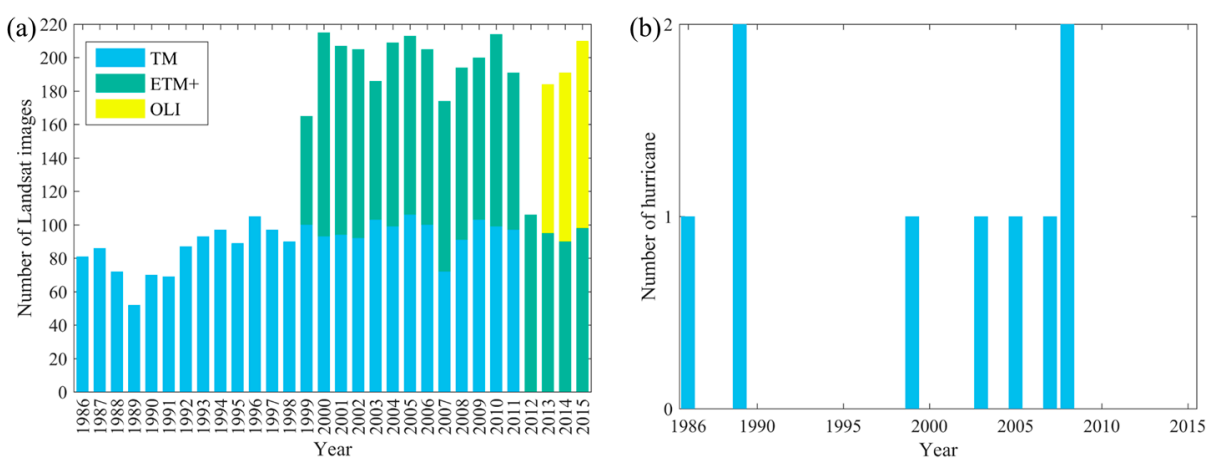

Figure 2. (a) Annual distribution of Landsat images; (b) Temporal distribution of hurricane occurred in the study area. (TM: Thematic Mapper, ETM+: Enhanced Thematic Mapper Plus and OLI: Operational Land Imager).

Table 1. Summarized information of Landsat images used in this study. TM: Thematic Mapper, ETM+: Enhanced Thematic Mapper Plus and OLI: Operational Land Imager.

\begin{tabular}{lccccc}
\hline \multirow{2}{*}{ Path/Row } & Level & \multicolumn{3}{c}{ Scene Amount per Sensor } & \multirow{2}{*}{ Total Amount per Scene } \\
\cline { 3 - 5 } & & TM & ETM+ & OLI & \\
\hline $024 / 039$ & L1T & 372 & 284 & 48 & 704 \\
$025 / 039$ & L1T & 396 & 279 & 53 & 730 \\
$025 / 040$ & L1T & 387 & 286 & 47 & 722 \\
$026 / 040$ & L1T & 379 & 282 & 50 & 719 \\
$026 / 041$ & L1T & 369 & 288 & 52 & 719 \\
$026 / 042$ & L1T & 401 & 299 & 52 & 763 \\
\hline
\end{tabular}

\subsection{Validation Data}

Light detection and ranging (LIDAR) data and water level from Galveston station were used for validating the land-water map derived from the Landsat image. LIDAR data was obtained from the website of Texas Natural Resources Information System (https:/ / tnris.org/data-catalog/). Such data was acquired in July 2006 with an altitude datum of North American Vertical Datum of 1988. Specifically, a high-density LIDAR elevation data map of Galveston County, Texas was collected. It provides a bare earth digital elevation model (DEM) after removing the vegetation. Then, a raster DEM with a spatial resolution of $1.4 \mathrm{~m}$ was generated using the raw point file based on ArcGIS 10.2. The spatial resolution of $1.4 \mathrm{~m}$ is fine enough for validation of land-water map with $30 \mathrm{~m}$ derived from Landsat images. Water level was obtained from the website of National Oceanic and Atmospheric Administration (https:/ / www.co-ops.nos.noaa.gov/) with the same altitude datum of the LIDAR data.

\subsection{Hurricane Data}

The historical hurricane records were obtained from the Unisys Weather website [44]. With the hurricane tracking information, the annual number of hurricanes making landfall in the State of Texas was computed and presented in Figure $2 b$.

\subsection{Sea Level Data}

Sea level rise is one of the important drivers of the position change of sandy coastline according to the Bruun Rule [45]. The sea level data was provided by the Rockport station (number: 8774770) [46]. Here, the annual mean sea level (Figure 3) was used to study the linkage between the inter-annual variability of coastline position and sea level. Besides, hourly sea level of the Rockport station was used to estimate the effect of observation frequency on estimation of coastline change rate. 


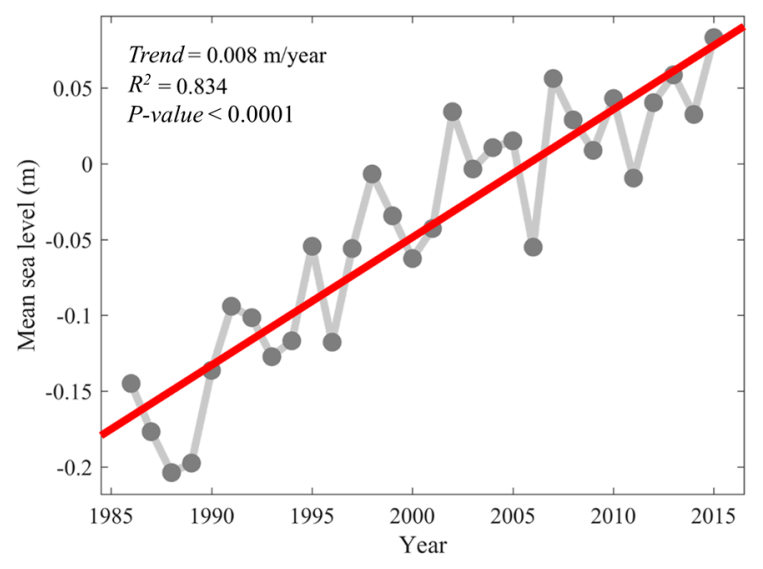

Figure 3. Observed annual sea level at Rockport station.

\section{Methodology}

The overall methodology was summarized in Figure 4. The detail steps are presented hereafter.

Detecting the long-term coastline change requires the following steps: (1) producing the time series of land vs. water maps from all Landsat imageries over 1986-2015; (2) defining the satellite imagerybased coastline and detecting the temporal change; (3) assessing the potential influencing factors.
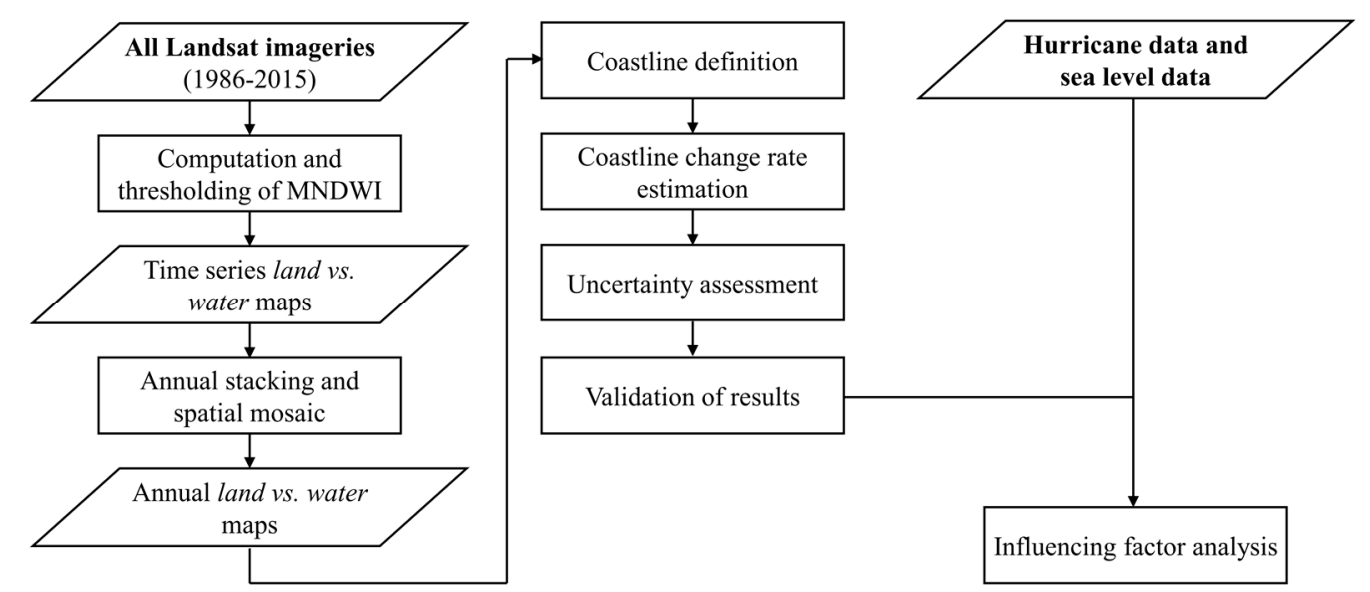

Figure 4. Summarized methodology for estimating the temporal change of coastline and analyzing the potential influencing factors.

\subsection{Annual Land-Water Maps Generation}

The Landsat Fmask product was applied to remove the clouds and cloud shadows in the initial Landsat imageries [47]. Then, modified Normalized Difference Water Index (MNDWI) was computed for effectively identifying land and water. The MNDWI is the modification of the Normalized Difference Water Index (NDWI), which has been widely used in previous studies [48,49]. Joshua's study shows that the MNDWI is the best index for automatic coastline mapping owing to its performance and threshold replicability [50]. Specifically, the MNDWI has the highest combined accuracy with $88.4 \%$ of both coastlines falling within the intertidal area based on the GPS-surveyed high tide lines and low tide lines. The MNDWI is expressed as:

$$
\text { MNDWI }=(\text { Green }- \text { MIR }) /(\text { Green }+ \text { MIR })
$$


where Green is the green band (band 2 for Landsat TM/ETM+ data and Landsat OLI data), MIR is the middle infrared band (band 5 for Landsat TM/ETM+ data and band 6 for Landsat OLI data, respectively).

Based on the results of MNDWI computation, the threshold value of zero was applied to map the extent of land and water [51-53]. In reality, zero was determined as the optimal threshold for land-water classification using receiver operator characteristic (ROC) curves [54]. As shown in Figure 5, threshold zero is stable and repeatable for coastline mapping based on the MNDWI and does not require calibration in various sites [50].

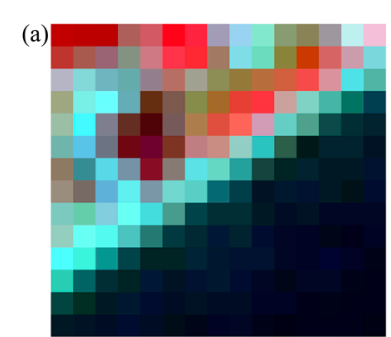

(c)

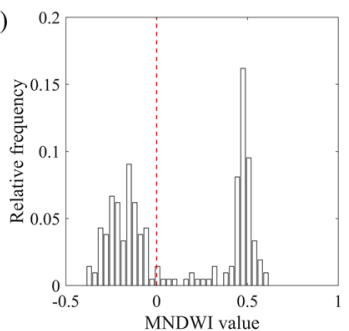

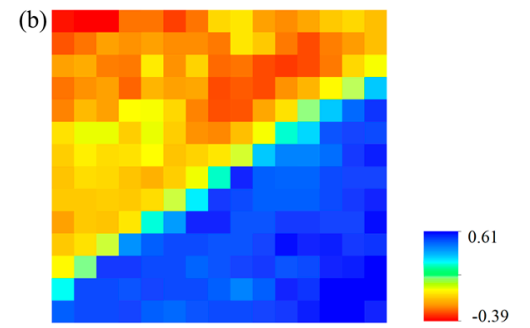

(d)

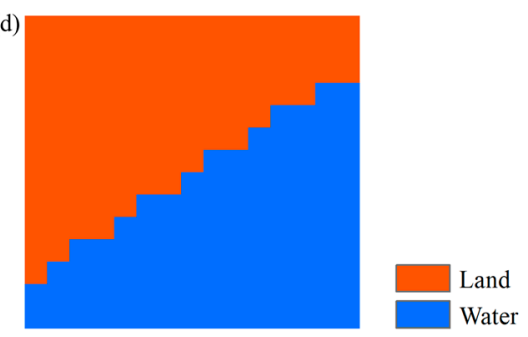

Figure 5. An example of generating a land-water classification map around the Galveston, Texas on 13 July 2006. (a) Landsat false color composite image (band 432); (b) The modified Normalized Difference Water Index (MNDWI) map; (c) The frequency distribution of all data values of the MNDWI image; (d) Land-water classification map. In (c), the blue dashed line represents the zero-threshold for classifying land and water pixels.

Finally, all Landsat imageries were classified into three classes: (1) Land; (2) Water and (3) Nodata (i.e., clouds and shadows). In each year, all land cover maps were stacked together for counting the number of pixels classified as water or land for each location. The water frequency index (WFI) at an annual scale was computed using the following formula:

$$
\mathrm{WFI}=\mathrm{N}_{\text {water }} /\left(\mathrm{N}_{\text {land }}+\mathrm{N}_{\text {water }}\right)
$$

where $\mathrm{N}_{\text {water }}$ and $\mathrm{N}_{\text {land }}$ are the number of pixels that were observed as water and land within one year, respectively.

Figure $6 \mathrm{c}$ shows the WFI map around the Galveston, Texas in 2006.The pixels with the value of WFI greater or equal to 0.5 were reclassified as water areas at annual scale (Figure 6d). The morphological operations (i.e., filling operator) were then applied for removing the pixels of inland water and noise. Such land vs. water maps were used to characterize the annual average coastline positions, which can minimize the impact of short-term coastal changes resulted from sea level variations, the length of wave run-up, sedimentary seasonal changes in the beach profile and coastal storms [34]. Specifically, using the median method allows us to solve a number of potential problems with the Landsat observations as follow: (1) data gaps such as Landsat 7 Enhanced Thematic Mapper Plus $(\mathrm{ETM}+)$ Scan Line Corrector (SLC)-off gap striping; (2) residual noise and confounding factors not captured by pixel quality flagging (e.g., cloud, shadows and their edge pixels); (3) temporal random variations that may affect individual NDWI values [55]. Finally, a dataset of 30-year land vs. water maps was generated. 
(a)

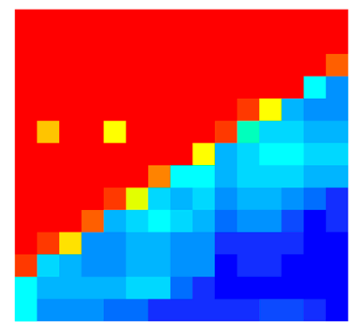

(c)

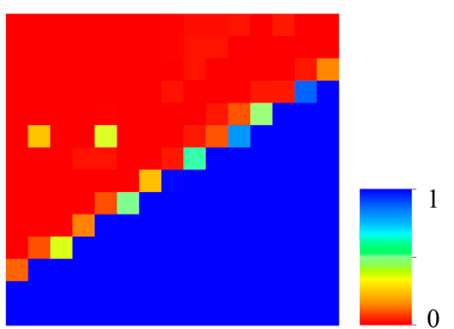

(b)

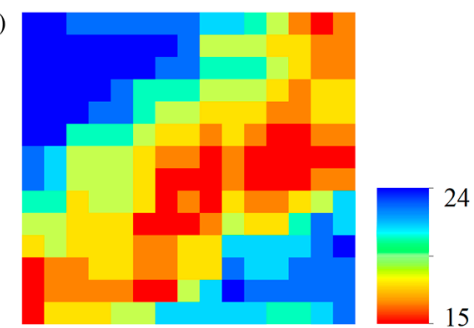

(d)

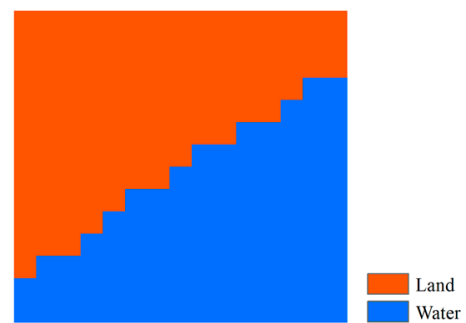

Figure 6. An example of generating an annual land-water map around the Galveston, Texas in 2006. (a) Heatmap showing number of clear observations per pixel around the Galveston, Texas during 2006; (b) Heatmap showing number of clear observations (i.e., without clouds and shadows) per pixel around the Galveston, Texas in 2006; (c) The WFI map in 2006; (d) The annual land-water classification map during 2006. A total of 38 Landsat images (21 TM images and 17 ETM+ images) were used for demonstrating the generation of the land-water map at an annual scale.

\subsection{Coastline Change Rate Estimation}

The transect-based method and the area-based method are two methods that have been widely used in coastline change rate estimation. In fact, the former was widely used for detecting the coastline change by computing the distance between the self-defined reference baseline and multi-temporal coastlines [16]. The baseline was manually generated along the coastline with various directions [56-58]. Transects were generated along the baseline with a given interval. This method can lose some information obtained from remotely sensed data because the interval between transects is always greater than $30 \mathrm{~m}$. Additionally, the baseline lacks consistent standards because it was designed manually. The latter evaluated the coastline change by comparing the change of land or water areas using multi-temporal land vs. water maps [19,59-61]. However, the area-based method can only use total land area change to characterize the coastline change and it is unable to obtain the coastline change rate along the coastline. In this study, the two methods were combined to calculate the coastline change rate. The method is described as follows.

First, the coastline in the Texas State of 2001 was selected as the base coastline, as 2001 is the middle of the study period. Then, the base coastline was divided into two portions according to their different orientations (Figure 7a). Specifically, the border between portion 1 and portion 2 for each of the sampled coastline pixels is located in the coastline from southwest to northeast with $45^{\circ}$. After the division, the coastline in portion 1 is more parallel to $x$-axis and coastline in portion 2 is more parallel to $y$-axis, which results in the classification shown in Figure 7a. Change rate of coastline in portion 1 and portion 2 was calculated with similar steps. For portion $1, x$-axis was used as the baseline and the midline is perpendicular to $x$-axis. For Section 2, $y$-axis was used as the baseline and the midline is perpendicular to $y$-axis. Here, we took portion 1 as an example to demonstrate the method of coastline change rate estimation. First, for one year, the land area was divided into many land sections with 10-pixel widths. Correspondingly, the coastline was divided into many coastline sections. The length of midline was calculated by dividing the land section area by the width (i.e., $300 \mathrm{~m}$ ), which represents the average coastline position of the coastline section of this year. These steps were conducted for each year to obtain the annual coastline position of each coastline section. Second, the long-term change rate of the midline length was estimated as the coastline change rate using the linear regression. All the 
elements used were presented in Figure $7 \mathrm{~b}$. The averaged change rate of the coastline of Texas was computed for characterizing the magnitude of coastline retreat or expansion. Note that a result with more spatial details can be obtained after the division of portion 1 and portion 2 with a 10-pixel land section. In addition, the total land area was used to represent the coastline position at state scale. Temporal analysis of coastline in the Texas State was conducted using the annual land area (Sections 4.2 and 4.3).
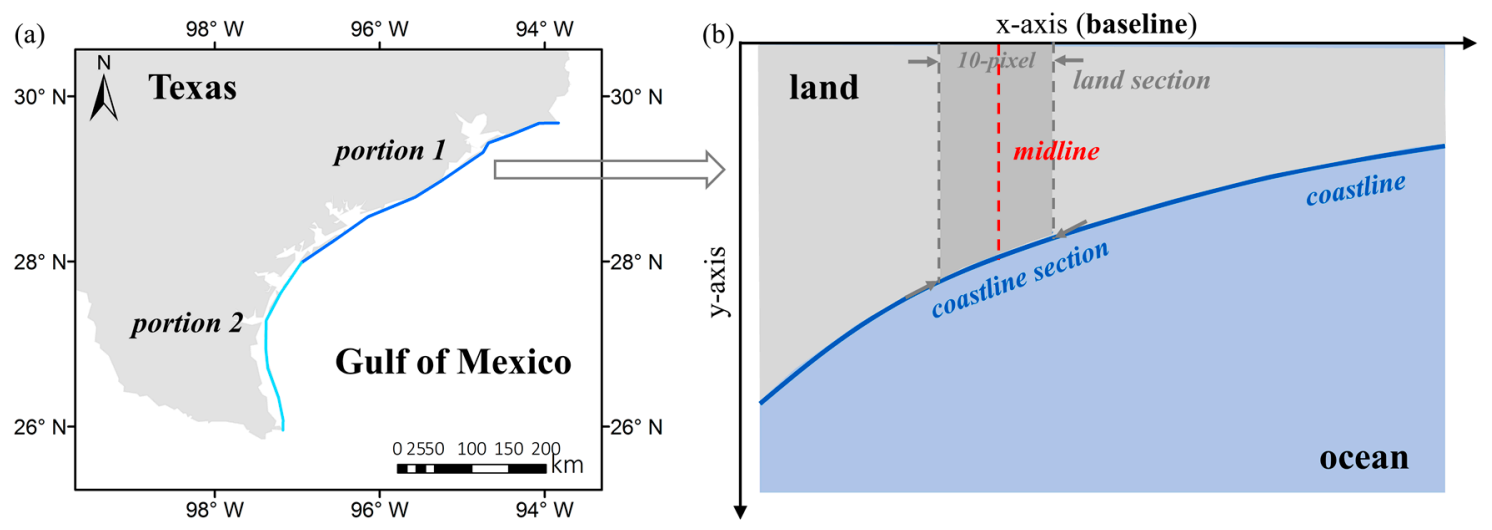

Figure 7. Illustration of the estimation of coastline change rate. (a) portion 1 and portion 2 in the Texas State; (b) elements used for defining the coastline and estimating the rate of coastline change.

\subsection{Uncertainty Assessment}

Being jointly determined by coastal topography and sea level, the area of each land section has an innate temporal auto-correlation, which should be considered to the estimation of coastline change rate. Thus, for each land section, the freedom degree was computed using the Quenouille procedure [62]. The standard deviation was calculated using the resulting freedom value for assessing the uncertainty.

\subsection{Impact of Hurricane on Coastline Change}

Previous studies suggested that hurricanes can alter the geomorphology of coast and further affect the coastline position $[63,64]$. To quantitatively assess the hurricane-induced impact on coastline change, a hurricane frequency index (HFI) was introduced, which was similar to the storm frequency index developed by Nebel [65]. HFI is defined as follows:

$$
\text { Hurricane Frequency Index }=\frac{n}{y}
$$

where $n$ is the number of hurricanes occurred in study area, and $y$ is the temporal interval. A 5-year interval was used in this study.

Besides, a hurricane concentration index $(\mathrm{HCI})$ was defined to indicate the degree of concentration of hurricanes. This index was defined as the standard deviation of the time that hurricanes occurred in the study area:

$$
\text { Hurricane Concentration Index }=\operatorname{STD}(\mathrm{T})
$$

where $\mathrm{T}$ is the timing sequence of hurricanes $\left\{t_{1}, t_{2}, t_{3}, \ldots t_{n}\right\}$.

During the temporal interval of 5 years, we performed a linear regression between the change rates and the two indexes for reflecting the impact of hurricanes on coastline change.

\subsection{Impact of Sea Level Variation on Coastline Change}

Both sea level and coastline position varied at different temporal scales. Sea level rise results in the retreat of coastline position to land by mainly changing the coastal geomorphologies at a larger 
temporal scale [66]. Moreover, coastlines may shift when the sea level fluctuates at a smaller temporal scale [67]. Here, two terms of sea level data (i.e., trend term and fluctuation term) were used for studying the relationship between sea level variation and change of coastline position.

The sea level variability at a monthly scale was collected for studying its association with trend term of coastline position. First, a moving average filter was applied to obtain the trend term of sea level. Then, the residual between the smoothed result and annual sea level was used as the fluctuation term of sea level for measuring the temporal variability. Correspondingly, the position of coastline was also decomposed into the trend term and fluctuation term using the same method. Finally, we performed a correlation analysis between coastline position and sea level. The correlation analysis was also implemented between the change rate of coastline position and sea level. Note that the trend term of coastline position and sea level is used herein and the study period of 1986-2015 was divided into six 5-year intervals for estimation of change rate.

\subsection{Coastline Morphology Anlysis}

In this study, the curvature was calculated to measure the morphology (i.e., concave/convex) of the coastline. Note that the curvature is positive when the local coastline is convex to the land while the curvature is negative when the local coastline is convex to the ocean. For each center coastline section, a 1001-coastline section moving spatial window was used to generate the mean local curvature (MLC). Coastline sections with a higher curvature and a lower curvature compared with the mean coastline change rate were grouped. Then, the mean coastline change rates of coastline sections with a higher curvature and a lower curvature compared with the mean coastline change rate were calculated, respectively. Change rates of coastline sections with a higher curvature and a lower curvature were compared to explore the possible linkage between the coastline morphology and coastline change.

\subsection{Effect of Observation Frequency on Estimation of Coastline Change Rate}

The fluctuation of coastline position was mainly controlled by the fluctuation of sea level based on the assumption that the coastal slope is stable. Given the average slope of $1 / 25$ in Texas [36], the impact of observation frequency on coastline position was assessed using the Monte Carlo simulation method. First, for each simulation, the observation frequency of Landsat was randomly generated (i.e., 1 to 30 in each year) and the mean sea level was calculated based on hourly sea level time series. Second, the process was repeated 10,000 times and the standard deviation was computed as the uncertainty of coastline position at an annual scale.

At a long-term scale, the annual sea level uncertainty can result in the uncertainty of coastline change rate. We achieved the relationship between the observation frequency and the uncertainty of coastline change rate using the average coastline change rate obtained in Section 3.2.

\section{Results}

\subsection{Spatial Pattern Analysis of Coastline Change}

The change rates and the corresponding uncertainties were calculated along the coastline in the State of Texas. Figure 8 presents the spatial distribution of coastline change rates during the study period. In this region, the change rates vary spatially, ranging from -29.51 to $40.32 \mathrm{~m} /$ year. $52.58 \%$ of coastline experienced erosion (i.e., with a negative value), but only $6.54 \%$ of coastline experienced erosion with the rate value less than $-5 \mathrm{~m} /$ year (red dots). Moreover, $47.42 \%$ of coastline experienced accretion (i.e., with a positive value), but only $4.02 \%$ of coastline experienced accretion rates greater than $5 \mathrm{~m}$ /year (green dots).

As shown in Figure 8, the coastline retreat was mainly concentrated in the northeast and southwest of the State of Texas. The coastline retreat rate in northeast Texas is higher than in the southwest. Moreover, the coastline around Port $\mathrm{O}^{\prime}$ Connor exhibited an advance to the ocean. Additionally, the coastline around some estuaries or inlets exhibited a relatively large change. Figure 9 shows 
the uncertainty map of estimation of coastline change rates. We found that the uncertainty is relatively low between Port Isabel and Port Aransas. Additionally, the uncertainty is relatively high around some estuaries or inlets. Among the total 1742 coastline sections of study area, $37.03 \%$ were characterized by statistically significant accretion and $41.45 \%$ by statistically significant erosion. The state average change rate over all the coastline sections and its uncertainty were $-0.27 \mathrm{~m} /$ year and $0.06 \mathrm{~m}$ /year, respectively.

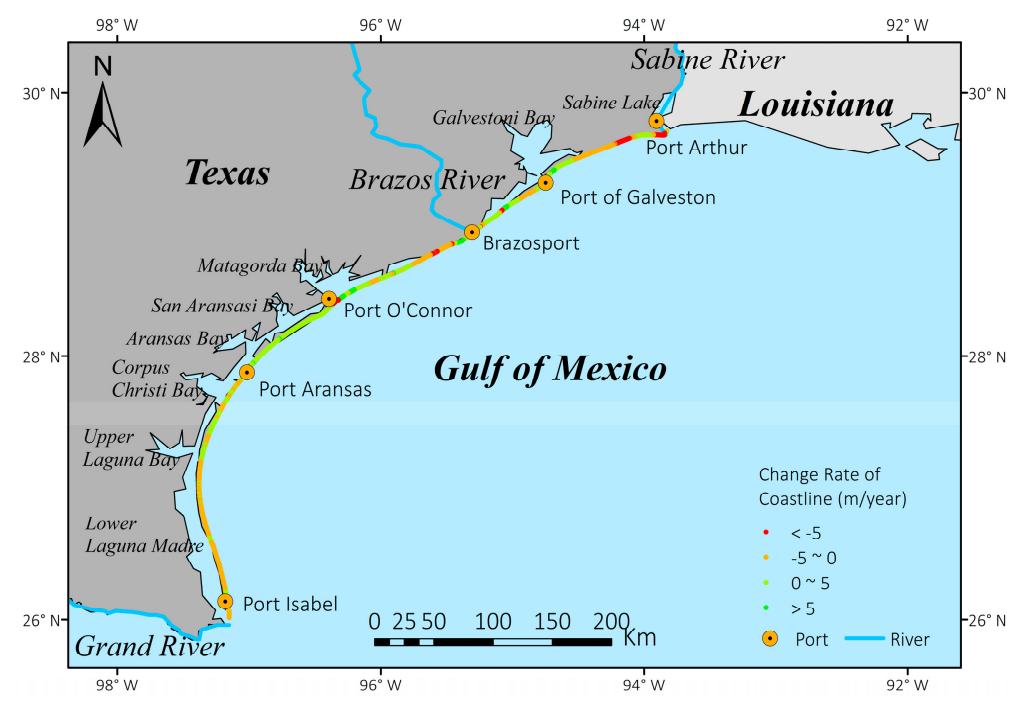

Figure 8. Spatial distribution of coastline change rates in the State of Texas.

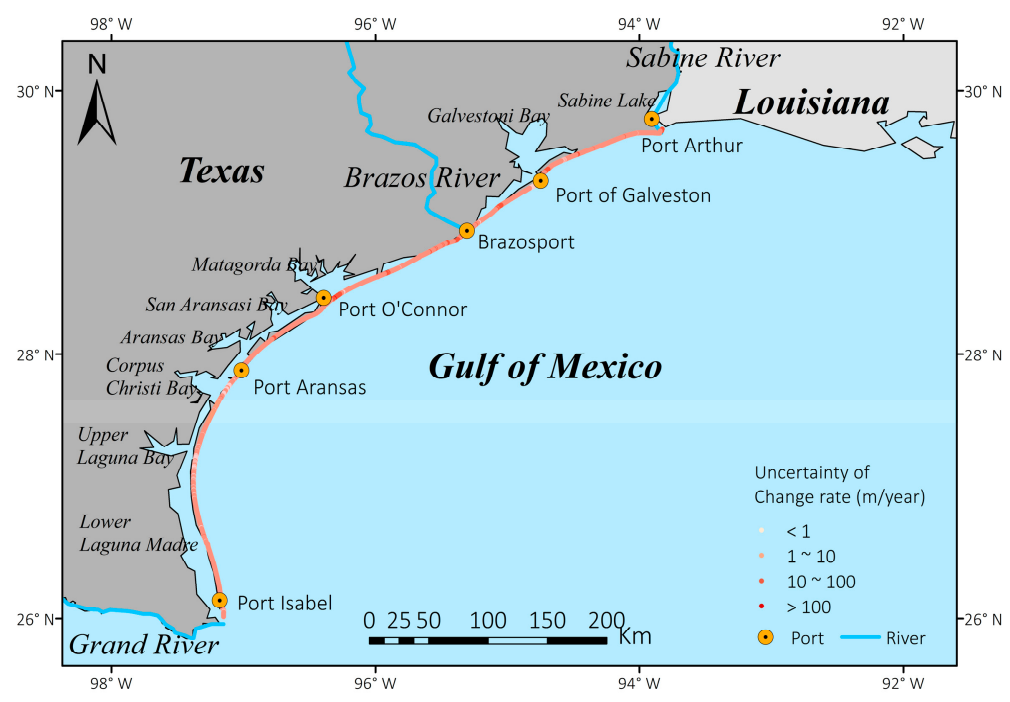

Figure 9. Spatial distribution of uncertainties of coastline change rates in the State of Texas.

\subsection{Temporal Variation Analysis of Coastline Change}

The annual land area at the state scale was calculated to characterize the average position of coastline (Figure 10a). The coastline change rate over 1986-2015 and its uncertainty were $-0.154 \mathrm{~km}^{2} /$ year and $0.063 \mathrm{~km}^{2} /$ year, respectively. The results suggest that this region mainly experienced erosion from 1986 to $2015\left(R^{2}=0.320, p\right.$-value $\left.=0.001\right)$. We also calculated the change rates for the three intervals of 1986-2002, 2003-2009 and 2010-2015 to describe the temporal variation (Figure 10b). Two obvious tipping points can be discovered in 2003 and 2009.

Specifically, the coastline retreated to the land at a rate of $-0.146 \pm 0.086 \mathrm{~km}^{2} /$ year from 1986 to $2002\left(R^{2}=0.147, p\right.$-value $\left.=0.129\right)$ and retreated to the land at a rate of $-0.501 \pm 0.332 \mathrm{~km}^{2} /$ year from 
2003 to $2009\left(R^{2}=0.314, p\right.$-value $\left.=0.191\right)$, but it advanced to the ocean at a rate of $1.068 \pm 0.543 \mathrm{~km}^{2} /$ year from 2010 to $2015\left(R^{2}=0.633, p\right.$-value $\left.=0.058\right)$.

We found that the land area reached its lowest level (Figure 10a) after some hurricane events during 2003-2008 that will be further discussed in Section 4.3. In the absence of a hurricane, the coastline started to advance to the ocean during 2009-2015, which might be explained as beach recovery from the damage of previous hurricanes $[4,68]$.
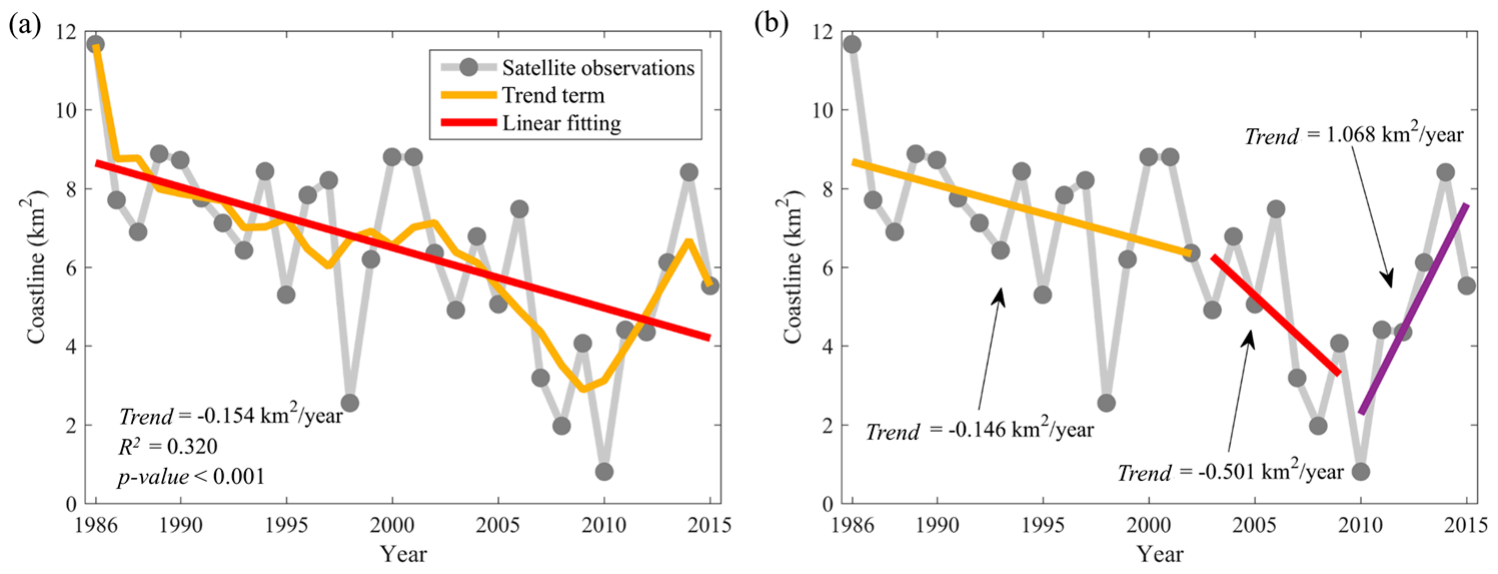

Figure 10. Temporal variation in the position of the coastline for the State of Texas: (a) 5-year trend curve and linear regression during the period 1986-2015; (b) linear regression performed in three temporal intervals.

\subsection{Influencing Factor Analysis}

The results of the influencing factors analysis conducted on hurricane and sea level variation are presented. Both HFI and HCI have a negative correlation with the change rate of coastline position at the scale of five years, with the linear regression coefficient $\left(R^{2}\right)$ equal to 0.71 and 0.66 , respectively (Figure 11a,b). Figure 12a suggests that the relationship between trend term of coastline position and sea level $\left(R^{2}=0.594, p\right.$-value $\left.<0.001\right)$. Figure $12 \mathrm{~b}$ shows that the rates of sea level rise are strongly associated with the coastline change rates $\left(R^{2}=0.966, p\right.$-value $\left.<0.001\right)$. As shown in Figure 13, significant difference between the coastline change rate with a higher curvature and a lower curvature was observed.
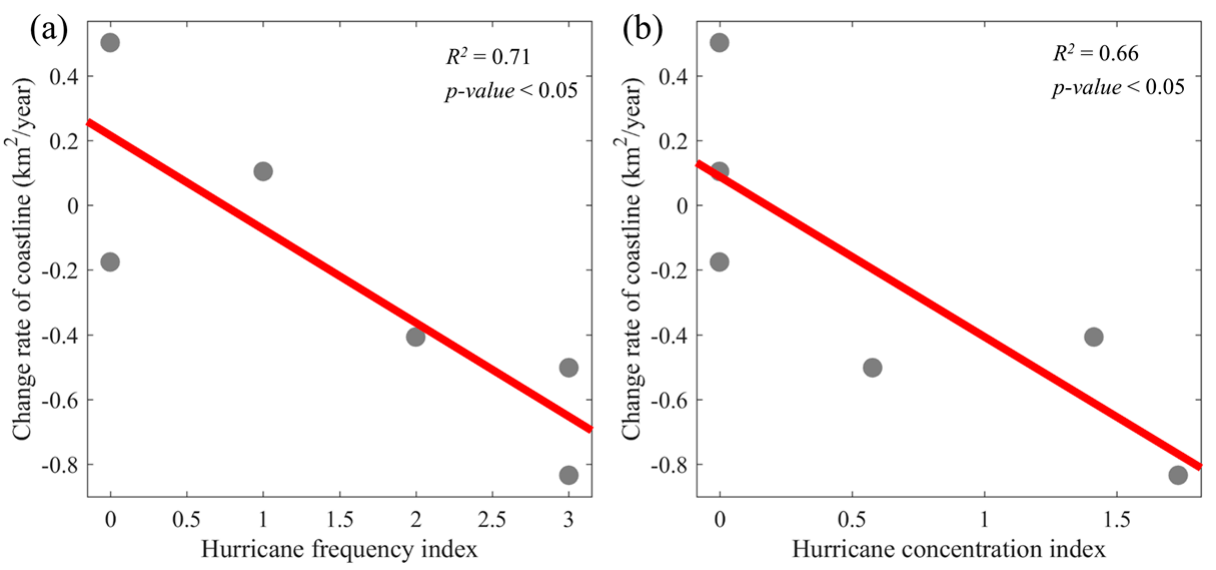

Figure 11. (a) Relationship between coastline change rate and hurricane frequency; (b) Relationship between coastline change rate and hurricane concentration. 

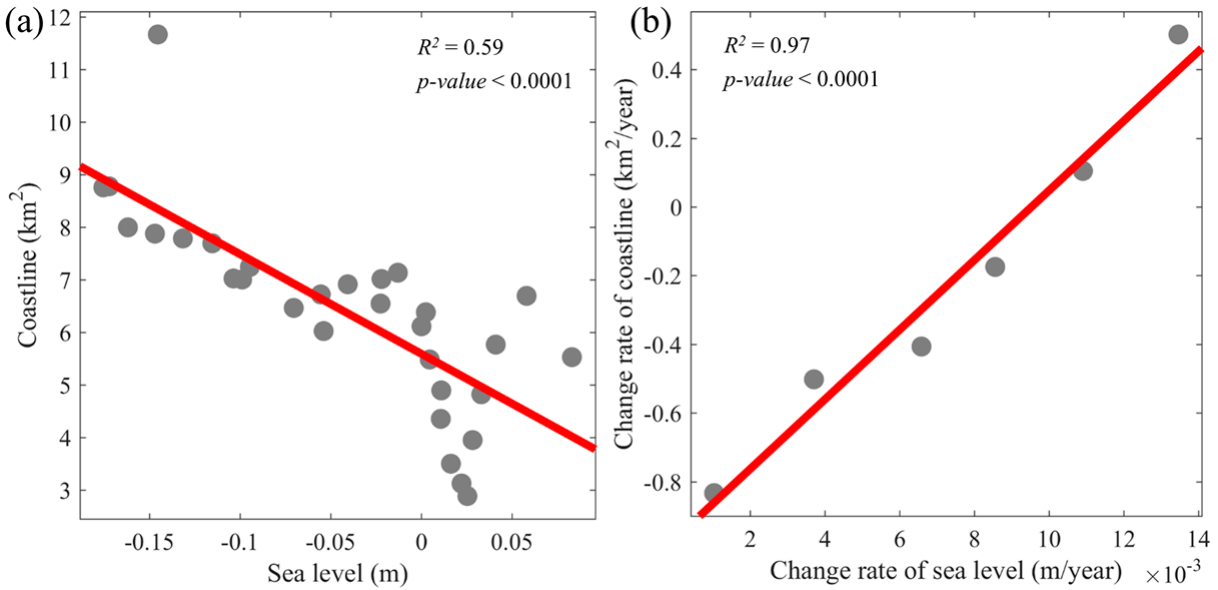

Figure 12. Relationship between the change of coastline position and sea level: (a) annual coastline position and sea level; (b) change rate of coastline position and sea level during the periods 1986-1990, 1991-1995, 1996-2000, 2001-2005, 2006-2010 and 2011-2015, respectively.

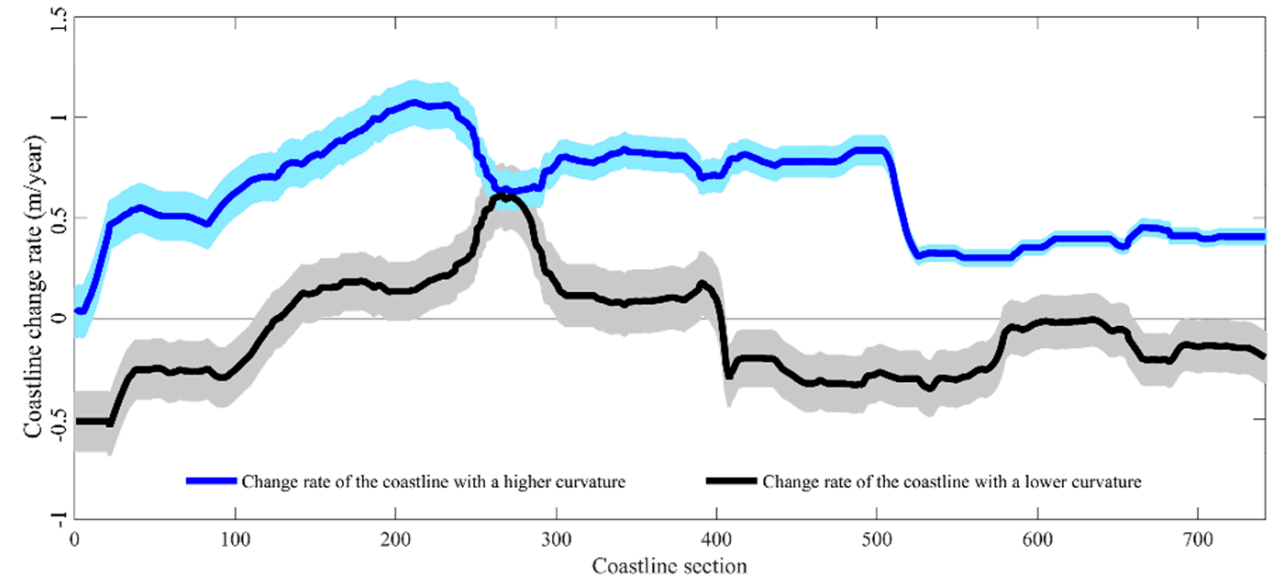

Figure 13. Comparison of coastline change rate with a higher (blue) coastline curvature and a lower (black) coastline curvature. The shadow area demonstrates corresponding confidence intervals. Number of coastline section on the horizontal axis indicate the central number of the moving spatial window used to derive the mean change rate of coastline.

\subsection{Validation of Land-Water Map Using LIDAR Data}

The coastline derived from the Landsat data was validated by mapping the result from corresponding LIDAR data. Figure 14 shows the validation results for a coastline with sandy beach around Galveston, Texas. Figure 14a is the high-resolution image from google earth. Figure 14b is the LIDAR-based DEM. Figure 14c represents the LIDAR-derived land-water map based on the water level correspond to the Landsat observation. The water level of the Landsat image was obtained from the National Oceanic and Atmospheric Administration (NOAA) website. The LIDAR-derived coastline was resampled to $30 \mathrm{~m}$ (the spatial resolution of Landsat data) for comparison with the Landsat-derived land-water map. As shown in Figure 14d, inconsistent pixels between two land-water maps were labeled with yellow (i.e., error pixels). In the selected area, only two incorrect pixels were produced, which suggest a higher mapping accuracy. 
(a)

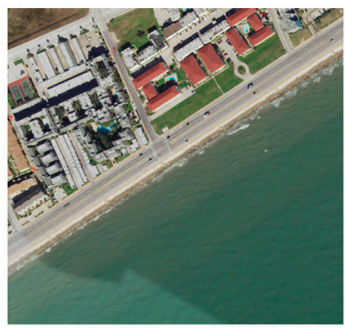

(c)

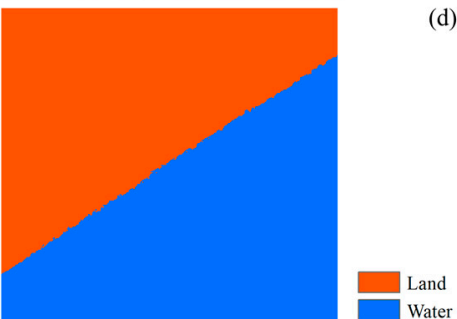

(b)

(d)
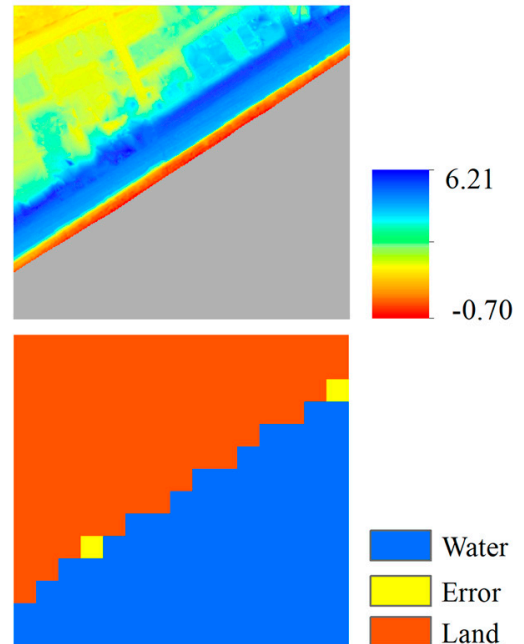

Figure 14. An example of generating an annual land-water map using Landsat images around the Galveston, Texas in 2006. (a) high-resolution image from google earth; (b) light detection and ranging (LIDAR)-based digital elevation model (DEM); (c) LIDAR-derived land-water map; (d) two land-water maps derived from LIDAR data and Landsat images.

\subsection{Validation of Coastline Change in the Texas State}

The coastline change information in the Texas State derived from Landsat data was validated with the results from LIDAR data and aerial photographs with a high spatial resolution $[36,69,70]$. Note that in their studies, coastline in 2000, 2010, 2011 and 2012 was extracted from the LIDAR-derived DEM at about $0.6 \mathrm{~m}$ above local mean sea level. The coastline in 2007 was extracted from the aerial photographs using the wet beach/dry beach boundary. Specifically, the net land area change between different years was used to characterize the coastline change during five periods (i.e., 2000-2012, 2007-2010, 2010-2011, 2010-2012, 2011-2012). As shown in Figure 15, a good agreement was achieved $\left(R^{2}=0.83\right.$, $p$-value $<0.05)$ between the coastline change derived from Landsat data and results from other studies.

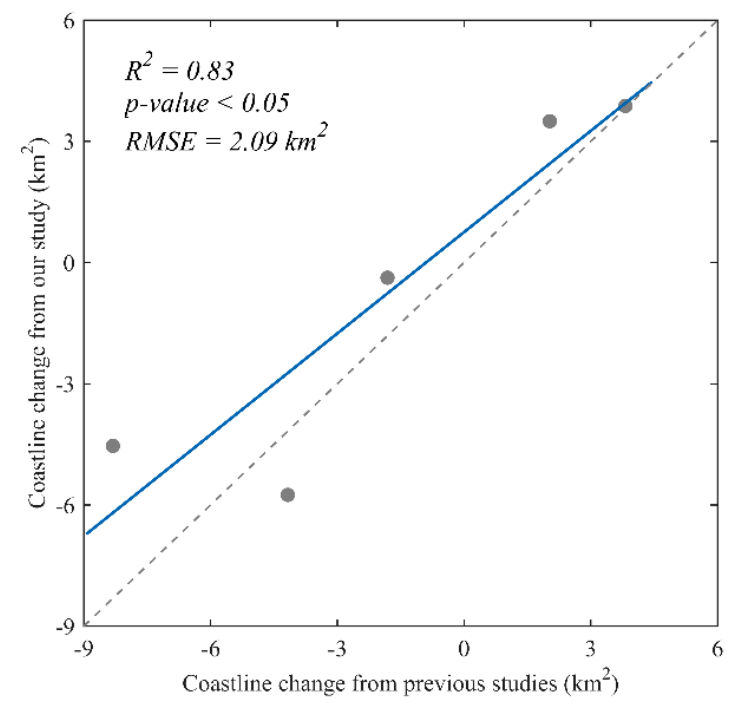

Figure 15. Comparison between our results and the results from previous studies. Grey points represent the coastline change during different years and the blue line represents the linear fitting line. The dashed grey line reflects the 1:1 line. 


\section{Discussions}

\subsection{Influencing Factors of Coastline Change}

From the results in Section 4.1, the coastline around some estuaries and inlets exhibited a relatively large change and a relatively high uncertainty. The rivers can transport sediments to the ocean from upstream. If the sediments reach the coastal zones, some sediments can deposit around estuaries and result in a change of coastline [71]. The coastline around inlets tends to advance to the ocean because the sediment from alongshore current can be stabilized by long jetties. Such jetties are constructed to maintain the inlet for boat traffic [71].

According to previous analysis in Section 4.3, coastline change in the State of Texas during the past 30 years was significantly linked with the HFI $\left(R^{2}=0.71, p\right.$-value $\left.<0.05\right)$ (Figure 11a) and $\mathrm{HCI}\left(R^{2}=0.66\right.$, $p$-value $<0.05$ ) (Figure 11b). The results of HFI show that the coastline is more likely to be eroded with more hurricanes, which suggests the importance of the damage (i.e., coastline erosion) on coastlines from hurricanes. Such results are in agreement with some previous studies [72,73]. The results of HCI highlight the impact of hurricane sequence on coastline change compared with isolated hurricanes. Our results indicate a significant negative correlation between the HCI and coastline change. It means that the impact on coastline of two hurricanes with a smaller interval is smaller than two hurricanes with a larger interval. Coco et al. also found that the sequence of extreme storms did not result in enhanced erosion [74]. Another study also obtained a similar conclusion and claimed that a storm group with an interval of one year (group of two storms) would induce erosion equivalent to the effect of a single storm with an interval of about 9 years [75]. Future climate change is predicted to lead to increased intensity of storms and hurricanes, which will continuously impact the coastline change [76].

Additionally, a significant relationship between long-term coastline position and sea level $\left(R^{2}=0.594, p\right.$-value $\left.<0.001\right)$ was observed (Figure 12a). We also found that the rates of sea level rise are strongly associated with the coastline change rates $\left(R^{2}=0.966, p\right.$-value $\left.<0.001\right)$ (Figure 12b). Our results were consistent with the Bruun Rule, which explains the linkage between the coastline change and sea level rise [66]. Such a relationship was also confirmed in Leatherman's study, which illustrates a high correlation $\left(R^{2}=0.89\right)$ between sea level rise and beach erosion along the U.S. east coast [77]. In the future, the continuous sea level rise may have a potential impact on coastline change. Moreover, the relationship between coastline change and sea level rise should be further examined at a larger spatial scale.

Hurricanes and sea level rise are two potential driving factors that contribute to the erosion of coastline. However, the alongshore sediment transport can also have an impact on the coastline change. In particular, it is likely to result in coastline accretion. In reality, eroding mainland shores and the continental shelf are the primary sources of sand for maintaining the beaches in the State of Texas [71]. Rivers around the State of Texas generally do not contribute significantly to the present sand budget of the beaches because they can only provide a very little sediment [78]. The eroding sand will move parallel to the coast by alongshore currents from the northeast to the southwest. Specifically, the sand tends to deposit around the concave coast owing to lower current velocity [79]. As a result, the coastline can advance to the ocean around these regions. Another study also gave a similar result and claimed that concave-shaped coastline tends to exhibit accretion while convex-shaped coastline tends to exhibit erosion [80], which was consistent with our result (Figure 13).

In addition, the sea level data from Rockport station is the relative sea level determined by absolute sea level changes and vertical land motion that can result from glacial isostatic adjustment, tectonic processes, coastal subsidence and uplift caused by anthropogenic factors [81]. Specifically, the change rate of vertical land movements calculated from the satellite altimeter data and tide gauge records in Rockport station is $-3.5 \mathrm{~mm} /$ year [81]. It means that the land subsidence occurred around Rockport, Texas. In the future, the land subsidence should be considered as a potential factor that affects coastline change in the Texas State. 
Apart from the natural factors, human activities can also influence the coastline change. Around some coastline, beach nourishment projects and coastline protection structures are constructed to prevent the erosion of coastline (preservation of private property and conservation of the beach) [71]. Moreover, beach nourishment is the most common method to reduce the damage caused by storms. Such methods can result in an artificial accretion of coastline in a short period [73]. Additionally, some jetties are constructed to maintain the inlet for boat traffic. Such operations can effectively reduce coastline erosion. Additionally, the submerged berm is another solution to beach erosion around tidal inlets [71]. It serves as a submerged breakwater causing large waves to break offshore and thus can reduce the coastline erosion caused by storms. In the future, more attention should be paid to distinguish the influence between natural factors and human activities. Assessing the contribution of natural factors and human activities to coastline change is needed for management and planning in coastal zones.

\subsection{Effect of Observation Frequency on Estimation of Coastline Change Rate}

It is clear that the uncertainty of coastline position is strongly negatively related to the observation frequency (Figure 16a). Similarly, the increase of observation frequency can reduce the uncertainty of coastline change rate (Figure 16b). The results suggest that increasing the observation frequency can effectively improve the accuracy of estimation of coastline change rate. It also states that using all the Landsat imageries over 1986-2015 is relevant for the State of Texas.

To further demonstrate the advantage of the method using high frequent observations, a section of coastline around Galveston, Texas was selected and the coastline area was presented (Figure 17). As shown in Figure 17b, yellow is the area of dynamic coastline in 2006. An intertidal zone with 2-pixel width was observed, which can represent the variation extent of coastline during one year. If only one Landsat image was used for the estimation of coastline change rate, some coastlines with tiny change cannot be observed owing to a 2-pixel variation extent of coastline during one year. The variation extent of coastline during one year make it necessary to make full use of all Landsat images to minimize the uncertainty caused by water level fluctuation. In reality, the multi-temporal Landsat stacking method has been used in some previous studies [55] for water detection and waterline delineation. Additionally, Almonacid-Caballer et al. also demonstrated that it is better to understand the coastline dynamics using such annual average coastlines [34].
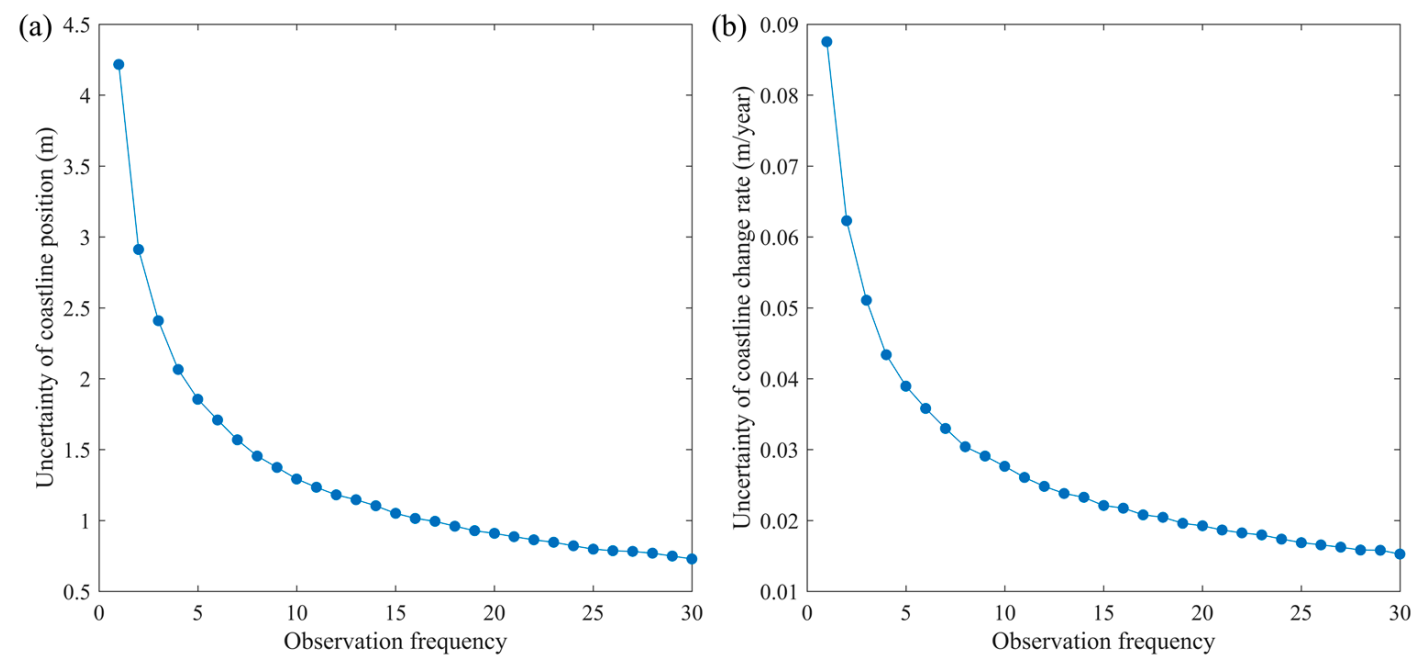

Figure 16. Impact of satellite observation frequency on the estimation of coastline change rate. $(\mathbf{a}, \mathbf{b})$ represent the association of observation frequency with uncertainty of coastline position and uncertainty of coastline change rate, respectively. 
(a)

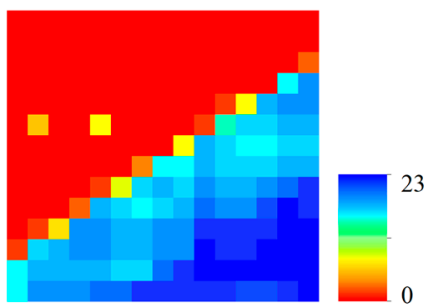

(b)

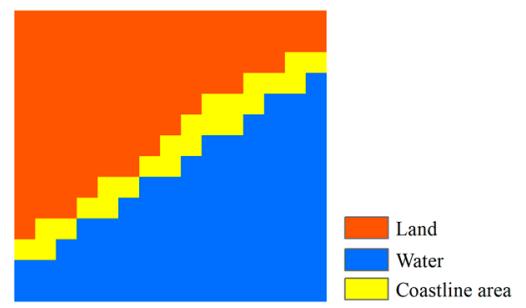

Figure 17. Demonstration of the variation of coastline around Galveston, Texas in 2006. (a) Heatmap showing number of clear observations per pixel around the Galveston, Texas during 2006; (b) The area of coastline during one year. In (b), orange represents the area always observed as land and blue represents the area always observed as water. Yellow indicates the variation extent of dynamics coastline during one year.

\subsection{Further Considerations}

The Landsat data permits both long-term and short-term continuous follow-up of the coastline position. However, the spatial resolution of $30 \mathrm{~m}$ might omit the tiny changes of coastline. Therefore, higher spatial resolution could be considered for this deficiency. For example, Sentinel-2 could realize the high frequent observations at large-scale from 2015 and provide four spectral bands with a spatial resolution of $10 \mathrm{~m}$. Moreover, optical imageries often present the limits due to the cloud cover. Synthetic aperture radar (SAR) sensors, such as Sentinel-1 and Phased Array L-band SAR (PALSAR), enable to penetrate such barrier and are easy to distinguish the land vs. water boundary using their cloud-penetrating capacity and day and night measurements.

Eventually, future works might focus on the extending this general approach to other areas with various coastline types for diachronically producing the coastline position and estimating the change rates. In addition, we need to pay more attention to estimate the contribution of human activities in coastal zones to the coastline change in the State of Texas.

\section{Conclusions}

This study developed a general method for detecting coastline change at larger spatial and long-term temporal scales by using satellite images. Coastline dynamics at an annual scale and the change rate over 1986-2015 for the State of Texas were obtained and presented. Our results were compared with the LIDAR data and some other studies. The spatial distribution of the change rate for each defined land section and its corresponding uncertainty were assessed. We also explored the association between the coastline change, sea level rise, hurricanes and alongshore sediment transport. The results show that the coastline in Texas State underwent erosion over the past three decades. This approach can easily be used in other study areas, where the beach dominates, and might also be adapted for estimating other coastlines types. In the future, more attention should be paid to exploring the impact of human activities on coastline change in the State of Texas.

Acknowledgments: We would like to thank Peng Gong (at Tsinghua University, Beijing), Arthur Philip Cracknell (at University of Dundee, Dundee), Wenyu Li (at Tsinghua University, Beijing), Zhichao Li (at Tsinghua University, Beijing), Zhenpeng Ge (at East China Normal University, Shanghai), Honglin Song (at Tongji University, Shanghai), Yaying Lin (at Tsinghua University, Beijing) for their constructive comments. We also thank anonymous reviewers for their insightful advice. This research was partially supported by Special Fund for Meteorology Scientific Research in the Public Welfare (GYHY201506010).

Author Contributions: Nan Xu designed the broad research strategy for the work, developed the methods, executed the analysis and finished the writing.

Conflicts of Interest: The author declare no conflict of interest. 


\section{References}

1. Yang, J.; Gong, P.; Fu, R.; Zhang, M.; Chen, J.; Liang, S.; Xu, B.; Shi, J.; Dickinson, R. The role of satellite remote sensing in climate change studies. Nat. Clim. Chang. 2013, 3, 875-883. [CrossRef]

2. Ranasinghe, R.; Callaghan, D.; Stive, M.J.F. Estimating coastal recession due to sea level rise: Beyond the Bruun rule. Clim. Chang. 2011, 110, 561-574. [CrossRef]

3. Zhang, K.; Douglas, B.C.; Leatherman, S.P. Global warming and coastal erosion. Clim. Chang. 2004, 64, 41-58. [CrossRef]

4. Fearnley, S.M.; Miner, M.D.; Kulp, M.; Bohling, C.; Penland, S. Hurricane impact and recovery shoreline change analysis of the Chandeleur Islands, Louisiana, USA: 1855 to 2005. Geo-Mar. Lett. 2009, 29, 455-466. [CrossRef]

5. Syvitski, J.P.M.; Kettner, A.J.; Overeem, I.; Hutton, E.W.H.; Hannon, M.T.; Brakenridge, G.R.; Day, J.; Vörösmarty, C.; Saito, Y.; Giosan, L.; et al. Sinking deltas due to human activities. Nat. Geosci. 2009, 2, 681-686. [CrossRef]

6. Jennings, S. Coastal tourism and shoreline management. Ann. Tour. Res. 2004, 31, 899-922. [CrossRef]

7. Tanaka, N.; Sato, S. Topographic change resulting from construction of a harbor on a beach: Kashima Port. Coast. Eng. 1976, 1977, 1824-1843.

8. Peterson, C.H.; Bishop, M.J. Assessing the environmental impacts of beach nourishment. Bioscience 2005, 55, 887-896. [CrossRef]

9. Muttitanon, W.; Tripathi, N.K. Land use/land cover changes in the coastal zone of Ban Don Bay, Thailand using Landsat 5 TM data. Int. J. Remote Sens. 2005, 26, 2311-2323. [CrossRef]

10. Shalaby, A.; Tateishi, R. Remote sensing and GIS for mapping and monitoring land cover and land-use changes in the northwestern coastal zone of Egypt. Appl. Geogr. 2007, 27, 28-41. [CrossRef]

11. Defeo, O.; McLachlan, A.; Schoeman, D.S.; Schlacher, T.A.; Dugan, J.; Jones, A.; Lastra, M.; Scapini, F. Threats to beach ecosystems: A review. Estuar. Coast. Shelf Sci. 2009, 81, 1-12. [CrossRef]

12. Cazenave, A.; Cozannet, G.L. Sea level rise and its coastal impacts. Earth's Future 2014, 2, 15-34. [CrossRef]

13. Le Cozannet, G.; Garcin, M.; Yates, M.; Idier, D.; Meyssignac, B. Approaches to evaluate the recent impacts of sea-level rise on shoreline changes. Earth-Sci. Rev. 2014, 138, 47-60. [CrossRef]

14. Boak, E.H.; Turner, I.L. Shoreline definition and detection: A review. J. Coast. Res. 2005, 214, 688-703. [CrossRef]

15. Gens, R. Remote sensing of coastlines: Detection, extraction and monitoring. Int. J. Remote Sens. 2010, 31, 1819-1836. [CrossRef]

16. Thieler, E.R.; Himmelstoss, E.A.; Zichichi, J.L.; Ergul, A. The Digital Shoreline Analysis System (DSAS) Version 4.0-An ArcGIS Extension for Calculating Shoreline Change (No. 2008-1278); US Geological Survey: Reston, VA, USA, 2009.

17. Shaw, J.B.; Wolinsky, M.A.; Paola, C.; Voller, V.R. An image-based method for shoreline mapping on complex coasts. Geophys. Res. Lett. 2008, 35, L12405. [CrossRef]

18. Li, W.; Gong, P. Continuous monitoring of coastline dynamics in western Florida with a 30-year time series of Landsat imagery. Remote Sens. Environ. 2016, 179, 196-209. [CrossRef]

19. Rahman, A.F.; Dragoni, D.; El-Masri, B. Response of the Sundarbans coastline to sea level rise and decreased sediment flow: A remote sensing assessment. Remote Sens. Environ. 2011, 115, 3121-3128. [CrossRef]

20. Honeycutt, M.G.; Crowell, M.; Douglas, B.C. Shoreline-position forecasting: Impact of storms, rate-calculation methodologies, and temporal scales. J. Coast. Res. 2001, 17, 721-730.

21. Karunarathna, H.; Reeve, D.E. A hybrid approach to model shoreline change at multiple timescales. Cont. Shelf Res. 2013, 66, 29-35. [CrossRef]

22. Ghoneim, E.; Mashaly, J.; Gamble, D.; Halls, J.; AbuBakr, M. Nile delta exhibited a spatial reversal in the rates of shoreline retreat on the Rosetta promontory comparing pre- and post-beach protection. Geomorphology 2015, 228, 1-14. [CrossRef]

23. Yu, K.; Hu, C.; Muller-Karger, F.E.; Lu, D.; Soto, I. Shoreline changes in west-central Florida between 1987 and 2008 from Landsat observations. Int. J. Remote Sens. 2011, 32, 8299-8313. [CrossRef]

24. Chen, W.-W.; Chang, H.-K. Estimation of shoreline position and change from satellite images considering tidal variation. Estuar. Coast. Shelf Sci. 2009, 84, 54-60. [CrossRef] 
25. Ford, M. Shoreline changes interpreted from multi-temporal aerial photographs and high resolution satellite images: Wotje atoll, Marshall Islands. Remote Sens. Environ. 2013, 135, 130-140. [CrossRef]

26. Frihy, O.E.; Dewidar, K.M.; Nasr, S.M.; El Raey, M.M. Change detection of the northeastern Nile Delta of Egypt: Shoreline changes, spit evolution, margin changes of Manzala lagoon and its islands. Int. J. Remote Sens. 1998, 19, 1901-1912. [CrossRef]

27. Fletcher, C.H.; Romine, B.M.; Genz, A.S.; Barbee, M.M.; Dyer, M.; Anderson, T.R.; Lim, S.C.; Vitousek, S.; Bochicchio, C.; Richmond, B.M. National Assessment of Shoreline Change: Historical Shoreline Change in the Hawaiian Islands; U.S. Department of the Interior: Washington, DC, USA, 2011.

28. Stockdonf, H.F.; Holman, R.A. Estimation of shoreline position and change using airborne topographic lidar data. J. Coast. Res. 2002, 18, 502-513.

29. Pianca, C.; Holman, R.; Siegle, E. Shoreline variability from days to decades: Results of long-term video imaging. J. Geophys. Res. Oceans 2015, 120, 2159-2178. [CrossRef]

30. Harley, M.D.; Turner, I.L.; Short, A.D.; Ranasinghe, R. Assessment and integration of conventional, RTK-GPS and image-derived beach survey methods for daily to decadal coastal monitoring. Coast. Eng. 2011, 58, 194-205. [CrossRef]

31. Gong, P. Remote sensing of environmental change over China: A review. Chin. Sci. Bull. 2012, 57, $2793-2801$. [CrossRef]

32. Hui, F.; Xu, B.; Huang, H.; Yu, Q.; Gong, P. Modelling spatial-temporal change of Poyang Lake using multitemporal Landsat imagery. Int. J. Remote Sens. 2008, 29, 5767-5784. [CrossRef]

33. Kovalskyy, V.; Roy, D.P. The global availability of Landsat 5 TM and Landsat 7 ETM+ land surface observations and implications for global $30 \mathrm{~m}$ Landsat data product generation. Remote Sens. Environ. 2013, 130, 280-293. [CrossRef]

34. Almonacid-Caballer, J.; Sánchez-García, E.; Pardo-Pascual, J.E.; Balaguer-Beser, A.A.; Palomar-Vázquez, J. Evaluation of annual mean shoreline position deduced from Landsat imagery as a mid-term coastal evolution indicator. Mar. Geol. 2016, 372, 79-88. [CrossRef]

35. Leatherman, S.P. Coastal geomorphic responses to sea-level Rise, Galveston Bay, Texas. In Greenhouse Effect and Sea-Level Rise: A Challenge for this Generation; Barth, M.C., Titus, J.G., Eds.; Van Nostrand Reinhold: New York, NY, USA, 1984; pp. 151-178.

36. Paine, J.G.; Caudle, T.L.; Andrews, J.R. Shoreline and sand storage dynamics from annual airborne Lidar surveys, Texas Gulf coast. J. Coast. Res. 2017, 33, 487-506. [CrossRef]

37. Sea Level Trends. Available online: https:/ / tidesandcurrents.noaa.gov/ (accessed on 1 July 2015).

38. Roth, D. Texas Hurricane History; Long Island Business News: New York, NY, USA, 2006.

39. Effect of Hurricane Ike in Texas. Available online: https:/ / en.wikipedia.org/wiki/Effects_of_Hurricane_ Ike_in_Texas\#cite_note-YNaft-2 (accessed on 1 July 2015).

40. Zane, D.F.; Bayleyegn, T.M.; Hellsten, J.; Beal, R.; Beasley, C.; Haywood, T.; Wiltz-beckham, D.; Wolkin, A.F. Tracking deaths related to hurricane Ike, Texas, 2008. Disaster Med. Public Health Prep. 2011, 5, $23-28$. [CrossRef] [PubMed]

41. Center, N.H. Tropical Cyclone Report Hurricane Ike (al092008) 1-14 September 2008; National Hurricane Center: Gainesville, FL, USA, 2008.

42. Song, C.; Woodcock, C.E.; Seto, K.C.; Lenney, M.P.; Macomber, S.A. Classification and change detection using Landsat TM data: when and how to correct atmospheric effects? Remote Sens. Environ. 2001, 75, 230-244. [CrossRef]

43. Lin, C.; Wu, C.C.; Tsogt, K.; Ouyang, Y.C.; Chang, C.I. Effects of atmospheric correction and pansharpening on LULC classification accuracy using WorldView-2 imagery. Inf. Process. Agric. 2015, 2, 25-36. [CrossRef]

44. Unisys Weather Information System. Available online: http://weather.unisys.com/hurricane/ (accessed on 1 July 2015).

45. Fitzgerald, D.M.; Fenster, M.S.; Argow, B.A.; Buynevich, I.V. Coastal impacts due to sea-level rise. Annu. Rev. Earth Planet. Sci. 2007, 36, 601-647. [CrossRef]

46. Real-time Water Level Information in the USA. Available online: https: / tidesandcurrents.noaa.gov/stations. html?type=Water+Levels (accessed on 1 July 2015).

47. Zhu, Z.; Woodcock, C.E. Object-based cloud and cloud shadow detection in Landsat imagery. Remote Sens. Environ. 2012, 118, 83-94. [CrossRef] 
48. Cui, B.L.; Li, X.Y. Coastline change of the Yellow River estuary and its response to the sediment and runoff (1976-2005). Geomorphology 2011, 127, 32-40. [CrossRef]

49. Li, Y.; Gong, X.; Guo, Z.; Xu, K.; Hu, D.; Zhou, H. An index and approach for water extraction using Landsat-OLI data. Int. J. Remote Sens. 2016, 37, 3611-3635. [CrossRef]

50. Kelly, J.T.; Gontz, A.M. Using GPS-surveyed intertidal zones to determine the validity of shorelines automatically mapped by Landsat water indices. Int. J. Appl. Earth Obs. Geoinf. 2018, 65, 92-104. [CrossRef]

51. Xu, H. Modification of Normalised Difference Water Index (NDWI) to enhance open water features in remotely sensed imagery. Int. J. Remote Sens. 2006, 27, 3025-3033. [CrossRef]

52. Sagin, J.; Sizo, A.; Wheater, H.; Jardine, T.D.; Lindenschmidt, K.E. A water coverage extraction approach to track inundation in the Saskatchewan River Delta, Canada. Int. J. Remote Sens. 2015, 36, 764-781. [CrossRef]

53. Acharya, T.; Yang, I.T.; Subedi, A.; Lee, D.H. Change detection of Lakes in Pokhara, Nepal using Landsat Data. In Proceedings of the 3rd International Electronic Conference on Sensors and Applications, online, 15-30 November 2016.

54. Fisher, A.; Flood, N.; Danaher, T. Comparing Landsat water index methods for automated water classification in Eastern Australia. Remote Sens. Environ. 2016, 175, 167-182. [CrossRef]

55. Sagar, S.; Roberts, D.; Bala, B.; Lymburner, L. Extracting the intertidal extent and topography of the Australian coastline from a 28 year time series of Landsat observations. Remote Sens. Environ. 2017, 195, 153-169. [CrossRef]

56. Romine, B.M.; Fletcher, C.H.; Frazer, L.N.; Genz, A.S.; Barbee, M.M.; Lim, S.C. Historical shoreline change, southeast Oahu, Hawaii; applying polynomial models to calculate shoreline change rates. J. Coast. Res. 2009, 25, 1236-1253. [CrossRef]

57. Houser, C.; Hapke, C.; Hamilton, S. Controls on coastal dune morphology, shoreline erosion and barrier island response to extreme storms. Geomorphology 2008, 100, 223-240. [CrossRef]

58. Ozturk, D.; Beyazit, I.; Kilic, F. Spatiotemporal analysis of shoreline changes of the Kizilirmak Delta. J. Coast. Res. 2014, 31, 1389-1402. [CrossRef]

59. Filho, P.W.M.S.; Martins, E.D.S.F.; Costa, F.R.D. Using mangroves as a geological indicator of coastal changes in the Bragança macrotidal flat, Brazilian Amazon: A remote sensing data approach. Ocean Coast. Manag. 2006, 49, 462-475. [CrossRef]

60. Chu, Z.X.; Sun, X.G.; Zhai, S.K.; Xu, K.H. Changing pattern of accretion/erosion of the modern Yellow River (Huanghe) subaerial delta, China: Based on remote sensing images. Mar. Geol. 2006, 227, 13-30. [CrossRef]

61. El-Raey, M.; Sharaf El-Din, S.H.; Khafagy, A.A.; Abo Zed, A.I. Remote sensing of beach erosion/accretion patterns along Damietta-port said shoreline, Egypt. Int. J. Remote Sens. 1999, 20, 1087-1106. [CrossRef]

62. Liao, E.; Lu, W.; Yan, X.H.; Jiang, Y.; Kidwell, A. The coastal ocean response to the global warming acceleration and hiatus. Sci. Rep. 2015, 5, 16630. [CrossRef] [PubMed]

63. Puig, M.; del Rio, L.; Plomaritis, T.A.; Benavente, J. Influence of storms on coastal retreat in SW Spain. J. Coast. Res. 2014, 70, 193-198. [CrossRef]

64. Anderson, T.R.; Frazer, L.N.; Fletcher, C.H. Transient and persistent shoreline change from a storm. Geophys. Res. Lett. 2010, 37, 162-169. [CrossRef]

65. Nebel, S.H.; Trembanis, A.C.; Barber, D.C. Tropical cyclone frequency and barrier island erosion rates, Cedar Island, Virginia. J. Coast. Res. 2013, 286, 133-144. [CrossRef]

66. Bruun, P. The Bruun rule of erosion by sea-level rise: A discussion on large-scale two-and three-dimensional usages. J. Coast. Res. 1988, 4, 627-648.

67. Splinter, K.D.; Turner, I.L.; Davidson, M.A. How much data is enough? The importance of morphological sampling interval and duration for calibration of empirical shoreline models. Coast. Eng. 2013, 77, $14-27$. [CrossRef]

68. Reif, M.K.; Macon, C.L.; Wozencraft, J.M. Post-Katrina land-cover, elevation, and volume change assessment along the south shore of lake Pontchartrain, Louisiana, U.S.A. J. Coast. Res. 2011, 62, 30-39. [CrossRef]

69. Paine, J.G.; Caudle, T.L.; Andrews, J.L. Shoreline Movement along the Texas Gulf Coast, 1930's to 2012; Final Report to the Texas General Land Office, Bureau of Economic Geology; the University of Texas: Austin, TX, USA, 2014.

70. Paine, J.G.; Mathew, S.; Caudle, T. Historical shoreline change through 2007, Texas Gulf Coast: Rates, contributing causes, and Holocene context. Gcags J. 2012, 1, 13-26. 
71. Morton, R.A.; Miller, T.L.; Moore, L.J. National Assessment of Shoreline Change: Part 1 Historical Shoreline Changes and Associated Coastal Land Loss along the U.S. Gulf of Mexico; USGS-U.S. Geological Survey, Center for Coastal \& Regional Marine Studies: Reston, VA, USA, 2004.

72. Morton, R.A. Stages and durations of post-storm beach recovery, Southeastern Texas Coast, U.S.A. J. Coast. Res. 1994, 10, 884-908.

73. Frazer, L.N.; Anderson, T.R.; Fletcher, C.H. Modeling storms improves estimates of long-term shoreline change. Geophys. Res. Lett. 2009, 37, 1437-1454. [CrossRef]

74. Coco, G.; Senechal, N.; Rejas, A.; Bryan, K.R.; Capo, S.; Parisot, J.P.; Brown, J.A.; MacMahan, J.H.M. Beach response to a sequence of extreme storms. Geomorphology 2014, 204, 493-501. [CrossRef]

75. Óscar, F. Storm groups versus extreme single storms: Predicted erosion and management consequences. J. Coast. Res. 2005, 21, 221-227.

76. Mulcahy, N.; Kennedy, D.M.; Blanchon, P. Hurricane-induced shoreline change and post-storm recovery: Northeastern Yucatan Peninsula, Mexico. J. Coast. Res. 2016, 2, 1192-1196. [CrossRef]

77. Leatherman, S.P.; Zhang, K.; Douglas, B.C. Sea level rise shown to drive coastal erosion. Eos Trans. Am. Geophys. Union 2000, 81, 55-57. [CrossRef]

78. Bullard, F.M. Source of beach and river sands on gulf coast of Texas. Geol. Soc. Am. Bull. 1942, 53, 1021-1043. [CrossRef]

79. Ells, K.D. Convexity, Concavity, and Human Agency in Large-Scale Coastline Evolution. Ph.D. Thesis, Duke University, Durham, NC, USA, 2014.

80. Phillips, J.D. Erosion and Planform Irregularity of an Estuarine Shoreline. Zeitschrift fiir Geomorphologie; Gerbruder Borntr: Berlin, Germany, 1989; pp. 59-71.

81. Letetrel, C.; Karpytchev, M.; Bouin, M.N.; Marcos, M.; Santamaríagómez, A.; Wöppelmann, G. Estimation of vertical land movement rates along the coasts of the Gulf of Mexico over the past decades. Cont. Shelf Res. 2015, 111, 42-51. [CrossRef]

(C) 2018 by the author. Licensee MDPI, Basel, Switzerland. This article is an open access article distributed under the terms and conditions of the Creative Commons Attribution (CC BY) license (http:/ / creativecommons.org/licenses/by/4.0/). 